\title{
The Influence of Risk Factors Toward The Time of Implementation The Road and Bridge Projects.
}

\author{
Latupeirissa Josefine Ernestine ${ }^{1}$, Irwan Lie K W ${ }^{2}$
}

\begin{abstract}
Construction of road and bridge infrastructure aimed to supporting the distribution of goods and human traffic and form a spatial structure. In construction, there are factors that affect the implementation time. Thus the purpose of this study was to identify risk factors that may affect the project implementation time, classified in categories, and how to influence and rank the likelihood of these factors. Research done by observation at the project site and interviews with interested parties. The data obtained were analyzed with a Likert Scale and Relative Importance Index (RII). While the interaction between risk factors with influence diagram. The study represent that there are 17 risk factors that always occur in the construction of roads and bridge in Papua, which affects the timing of implementation. These risk factors are classified into seven categories with the first dominant factor until the third in a sequence is $\mathrm{RII}=3.00, \mathrm{R}=1$ is Availability of Material(Material Aspects), Indigenous Land Issues( Natural and Social Aspects) and Schedule Delivery of Equipment and Material( Managerial Aspects); RII= 2,64, R=2 is Labor Expertise(Manpower Aspects), Quality of Material (Material Aspects), Land Acquisition (Natural and Social Aspects); and $R I I=2,52, R=3$ is Availability of Equipment (Equipment Aspects)
\end{abstract}

Keywords - risk factor, Roads project, time of the road construstion project

\section{Introduction}

The Government has compile up a project infrastructure to accelerate economic growth target of 6-7 per cent during the 2015 to 2019 according to the program of development. Government prioritize 71 potential infrastructure projects based on criteria: have a strategic value, to support economic growth, can be immediately implemented, beneficial for the socio-economic and environmental, as needed, and a recommendation ministries and local governments. Infrastructure has an important role and as one of the drivers of economic growth and development.

Infrastructure has an important role and as one of the drivers of economic growth and development. The existence of roads and bridges were adequate, indispensable. Limitations of infrastructure development of roads and bridges, causing the slowing pace of investment.

Latupeirissa Josefine Ernestine

Universitas Kristen Indonesia Paulus

Makassar- South Sulawesi - Indonesia

Irwan Lie K W

Universitas Kristen Indonesia Paulus

Makassar- South Sulawesi - Indonesia
Mastery of infrastructure such as roads and bridges are in the Government and Local Government in the implementation of delegated and or submitted to regional agencies or handed over to entities or individuals. Devolution and delegation of authority or organization of roads and bridges does not remove the responsibility of government. Regional autonomy, the implementation of roads and bridges are separated based on their authority.

Construction of roads and bridges in the area of West Papua aims to support the distribution of goods and human traffic and form a spatial structure. In construction there are risk factors that influence the implementation. Thus the purpose of this study was to identify risk factors that may affect the project implementation time, classified in categories, and how to influence and rank the likelihood of these factors.

\section{Infrastructure Project}

The basic physical systems of a business or nation. Transportation, communication, sewage, water and electric systems are all examples of infrastructure. These systems tend to be high-cost investments, however, they are vital to a country's economic development and prosperity. Infrastructure projects may be funded publicly, privately or through publicprivate partnerships.

\section{A. Road and Bridge Projects}

The road is land transportation infrastructure that includes all parts of the road including complementary buildings and equipment intended for traffic, which is at ground level, above ground, below ground and or water, as well as on the surface of the water, except railways, roads lorries, and the cable. While the construction of the bridge is a structure that serves to connect the two sections of road were cut off by the presence of obstacles such as deep valleys, river basins, lakes, irrigation canals and waster, highways and railways.

Roads and bridges as part of the transport infrastructure have an important role in the economic, social, cultural, environmental, political, defense and security and used for the prosperity of the people. The construction of roads and bridges as required by technical specifications needs to be done in sequence or stages of work right so the work more effective and can improve the efficiency of implementation, the possibility to reduce the cost of construction and can finish all the work on time.

The construction of roads and bridges are generally based on the flow chart, corresponding technical demands, the types and kinds of work in sequence to achieve the overall goal of 
Proc. of The Second Intl. Conf. On Advances in Civil, Structural and Mechanical Engineering - ACSM 2015

Copyright (C Institute of Research Engineers and Doctors, USA .All rights reserved.

ISBN: 978-1-63248-074-3 doi: 10.15224/ 978-1-63248-074-3-71

project completion. In the course of its implementation are small activities that are part of the main activities which should be implemented at the same time. In addition, the use of equipment in accordance with the correct method, and mastery of detail throughout the equipment used, will optimize the use of such equipment in order to improve production (Khisty\&Lall, 2003).

The Risk factors in implementation of road and Bridge projects

\section{B. The Risk Factors in Implementation of Road and Bridge Projects}

A risk factor implies that there is a range of outcomes for the event which could be both more and less favourable than the most likely outcome, and that each outcome within the range has a probability of occurrence. The accumulation or combination of risks can be termed project risk (Smith et al, 2006). The risk factor are always present in every construction project and is something that can not be ignored, but must be taken into account properly, if want to achieve the project objectives (Latupeirissa, 2007). On the implementation projects of road and bridge, adverse risk factors can hamper the completion of the project so as to slow the pace of investment. The risk factors include natural factors, financial, managerial and others.

\section{Influence Diagram}

An influence diagram (ID) is a way of describing the dependencies among aleatory variables and decisions. An influence diagram can be used to visualize the probabilistic dependencies in a decision analysis and to specify the states of information for which independencies can be assumed to exist. the purpose of modeling the influence diagram is to choose one of the alternative decisions that will generate the highest profits are expected. Symbol in the influence diagram is :

Decision node that represents a decision or control actions

Node representing risk factor

$\rightarrow$ The arrows that connect the node represent the influence of inter-node

$\diamond$ Value node that represents values such as time, cost or quality

(Alarcon, 1995 in Latupeirissa, 2007),

\section{Research Methods}

Primary data collection is direct observation in the field and interviews with responden yaitu contractors, supervisors and foremen, to determine the factors that affect the timing of the construction of road and bridge projects. How big is the influence of these factors were analyzed using a Likert Scale is a rating scale that uses ordinal measurement, namely :
Very impact $=3$

Moderate $=2$

No impact $=1$

Meanwhile, to measure the relative importance or impact of each factor using the formula Relative Importance Index (RII). Relative Importance Indeks (RII) is

$\mathrm{RII}=\frac{\sum_{i=1}^{3} W i X i}{\sum_{i=1}^{3} X i}$

(Odeh and Battaineh,2002)

Where :

$\mathrm{RII}=$ Relative Importance Index

$\mathrm{i}=$ Category Index Response (1, not important; 2, important; and 3 , very important)

$\mathrm{Wi}=$ Weight associated with the value of the respondents to the $\mathrm{i}$

$\mathrm{Xi}=$ The frequency of the response to $\mathrm{i}$ as a percentage of the total respondents for each factor

While the likely occurrence of these factors by respondents. Relationships between these factors and their impact on execution time illustrated with influence diagrams. The collection of secondary data covers contract documents, daily reports and monthly reports. This research conducted in West Papua where respondents selected contractor and subcontractor companies / specialists, directly involved in the road and bridge projects.

\section{Risk Factors Toward The Time of Implementation The Road and Bridge Projects}

\section{A. Classification of risk factors and their influence on the project implementation time}

Results identification of risk factors and how they affect, based on observations and interviews were classified in 7 Category. The classification into categories based on the source, characteristics, natural and logical related as shown in Table 1.

Table 1. Category of Risk Factor and The Impact

\begin{tabular}{|l|l|c|c|c|}
\hline No & $\begin{array}{c}\text { Risk Factor(RF) and } \\
\text { Risk Category (RC) }\end{array}$ & $\begin{array}{c}\text { Very } \\
\text { Impact } \\
(3)\end{array}$ & $\begin{array}{c}\text { Doubt } \\
(2)\end{array}$ & $\begin{array}{c}\text { Not } \\
\text { Impact } \\
(1)\end{array}$ \\
\hline RC1. & Manpower Aspects & & & \\
\hline RF1. & Labor Expertise & 20 & 1 & 4 \\
\hline RF2. & Labor availability & 15 & 2 & 8 \\
\hline RC2. & Material Aspects & & & 0 \\
\hline RF3. & $\begin{array}{l}\text { Availability of } \\
\text { Material }\end{array}$ & 25 & 0 & 4 \\
\hline RF4. & Quality of Materials & 20 & 1 & \\
\hline
\end{tabular}


Proc. of The Second Intl. Conf. On Advances in Civil, Structural and Mechanical Engineering - ACSM 2015 Copyright ( $)$ Institute of Research Engineers and Doctors, USA .All rights reserved.

ISBN: 978-1-63248-074-3 doi: 10.15224/ 978-1-63248-074-3-71

Table 1. .....continuation

\begin{tabular}{|c|c|c|c|c|}
\hline No & $\begin{array}{l}\text { Risk Factor(RF) and } \\
\text { Risk Category }(\mathrm{RC})\end{array}$ & $\begin{array}{c}\text { Very } \\
\text { Impact } \\
\text { (3) }\end{array}$ & $\begin{array}{l}\text { Doubt } \\
\text { (2) }\end{array}$ & $\begin{array}{l}\text { Not } \\
\text { Impact } \\
\text { (1) }\end{array}$ \\
\hline RC3. & Equipment Aspects & & & \\
\hline RF5. & $\begin{array}{l}\text { Availability of } \\
\text { Equipment }\end{array}$ & 18 & 2 & 5 \\
\hline RF6 & Quality of Equipment & 10 & 1 & 14 \\
\hline RC4. & $\begin{array}{l}\text { Characteristic } \\
\text { Location Aspects }\end{array}$ & & & \\
\hline RF7 & $\begin{array}{l}\text { Access to the project } \\
\text { site }\end{array}$ & 5 & 1 & 19 \\
\hline RF8 & Project location & 5 & 2 & 18 \\
\hline RC5. & $\begin{array}{l}\text { Natural and Social } \\
\text { Aspects }\end{array}$ & & & \\
\hline RF9 & Rainfall intensity & 15 & 0 & 10 \\
\hline RF10 & Indigenous land issues & 25 & 0 & 0 \\
\hline RF11 & land acquisition & 20 & 1 & 4 \\
\hline RC6. & Managerial Aspects & & & \\
\hline RF12 & $\begin{array}{l}\text { Project supervision } \\
\text { Experience of Manager }\end{array}$ & 16 & 1 & 8 \\
\hline RF13 & Experience of Manager & 16 & 1 & 8 \\
\hline RF14 & Error of estimate & 15 & 2 & 8 \\
\hline RF15 & $\begin{array}{l}\text { Schedule delivery of } \\
\text { equipment } \\
\text { and materials }\end{array}$ & 25 & 0 & 0 \\
\hline RC7. & $\begin{array}{l}\text { Economic and } \\
\text { Financial Aspects }\end{array}$ & & & \\
\hline RF16 & Payments by owner & 10 & 0 & 15 \\
\hline RF17 & Materials prices & 10 & 5 & 10 \\
\hline
\end{tabular}

\section{B. Relative Importance Index (RII) and $\operatorname{Rank}(R)$}

RII which is a formula used to determine the ranking of each of the risk factors that affect the timing of implementation, are shown in Table 2.

$$
\begin{aligned}
R I I & =\frac{(20 * 3)+(1 * 2)+(4 * 1)}{25} \\
& =2.64
\end{aligned}
$$

Table 2. Category of Risk Factor, RII and R

\begin{tabular}{|l|l|c|c|}
\hline No & \multicolumn{1}{|c|}{ RF and RC } & RII & R \\
\hline RC1. & Manpower Aspects & & \\
\hline RF1 & Labor Expertise & 2.64 & 2 \\
\hline RF2. & Labor availability & 2.28 & 5 \\
\hline RC2. & Material Aspects & & \\
\hline RF3 & Availability of Material & 3.00 & 1 \\
\hline RF4. & Quality of Materials & 2.64 & 2 \\
\hline
\end{tabular}

Table 2 ....continuation

\begin{tabular}{|l|l|c|c|}
\hline \multicolumn{1}{|c|}{ Ro } & \multicolumn{1}{|c|}{ RF and RC } & RII & R \\
\hline RC3. & Equipment Aspects & 2.52 & 3 \\
\hline RF5 & Availability of Equipment & 1.84 & 8 \\
\hline RF6 & Quality of Equipment & & \\
\hline RC4. & $\begin{array}{l}\text { Characteristic of Location } \\
\text { Aspects }\end{array}$ & 1.44 & 11 \\
\hline RF7 & Access to the project site & 1.48 & 10 \\
\hline RF8 & Project location & & \\
\hline RC5. & Natural and Social Aspects & 2.20 & 6 \\
\hline RF9 & Rainfall intensity & 3.00 & 1 \\
\hline RF10 & Indigenous land issues & 2.64 & 2 \\
\hline RF11 & Land acquisition & 2.32 & 4 \\
\hline RC6. & Managerial Aspects & 2.32 & 4 \\
\hline RF12 & $\begin{array}{l}\text { Project supervision } \\
\text { Experience of Manager }\end{array}$ & 2.28 & 5 \\
\hline RF13 & Experience of Manager & 3.00 & 1 \\
\hline RF14 & Error of estimate & 2.00 & 7 \\
\hline RF15 & $\begin{array}{l}\text { Schedule delivery of equipment } \\
\text { and materials }\end{array}$ & \begin{tabular}{l} 
\\
\hline RC7.
\end{tabular} Economic and Financial \\
Aspects & Payments by owner & 9 \\
\hline RF16 & Materials prices & & \\
\hline RF17 & and & & \\
\hline
\end{tabular}

\section{The probability of occurrence}

The probability value is to determine the likelihood of the occurrence of risk factors based subjective judgment, are shown in Table 3.

\begin{tabular}{|c|c|c|c|}
\hline No & $\mathrm{RF}$ and $\mathrm{RC}$ & $\begin{array}{c}\text { Probability } \\
\text { of } \\
\text { Occurrence }\end{array}$ & $\begin{array}{l}\text { No } \\
\text { Occurrence } \\
\text { Probability }\end{array}$ \\
\hline RC1. & Manpower Aspects & & \\
\hline RF1 & Labor Expertise & 0.80 & 0.20 \\
\hline RF2 & Labor availability & 0.65 & 0.35 \\
\hline RC2. & Material Aspects & & \\
\hline RF3 & Availability of Material & 0.95 & 0.05 \\
\hline RF4. & Quality of Materials & 0.80 & 0.20 \\
\hline RC3. & Equipment Aspects & & \\
\hline RF5 & $\begin{array}{l}\text { Availability of } \\
\text { Equipment }\end{array}$ & 0.75 & 0.25 \\
\hline RF6. & Quality of Equipment & 0.50 & 0.50 \\
\hline RC4. & $\begin{array}{ll}\text { Characteristic } & \text { of } \\
\text { Location Aspects } & \end{array}$ & & \\
\hline RF7. & $\begin{array}{l}\text { Access to the project } \\
\text { site }\end{array}$ & 0.40 & 0.60 \\
\hline RF8 & Project location & 0.40 & 0.60 \\
\hline RC5. & $\begin{array}{l}\text { Natural and Social } \\
\text { Aspects }\end{array}$ & & \\
\hline RF9 & Rainfall intensity & 0.60 & 0.40 \\
\hline RF10 & Indigenous land issues & 0.95 & 0.05 \\
\hline RF11 & Land acquisition & 0.80 & 0.20 \\
\hline
\end{tabular}

Table 3. 
Proc. of The Second Intl. Conf. On Advances in Civil, Structural and Mechanical Engineering - ACSM 2015

Copyright ( $)$ Institute of Research Engineers and Doctors, USA .All rights reserved.

ISBN: 978-1-63248-074-3 doi: 10.15224/ 978-1-63248-074-3-71

Table 3 ....continuation

\begin{tabular}{|c|c|c|c|}
\hline No & $\mathrm{RF}$ and $\mathrm{RC}$ & $\begin{array}{l}\text { Probability } \\
\text { of } \\
\text { Occurrence }\end{array}$ & $\begin{array}{c}\text { No } \\
\text { Occurrence } \\
\text { Probability } \\
\end{array}$ \\
\hline RC6. & $\begin{array}{l}\text { Managerial } \\
\text { Aspects }\end{array}$ & & \\
\hline RF12 & $\begin{array}{l}\text { Project supervision } \\
\text { Experience of } \\
\text { Manager }\end{array}$ & 0.70 & 0.30 \\
\hline RF13 & $\begin{array}{l}\text { Experience of } \\
\text { Manager }\end{array}$ & 0.70 & 0.30 \\
\hline RF14 & Error of estimate & 0.65 & 0.35 \\
\hline RF15 & $\begin{array}{l}\text { Schedule delivery } \\
\text { of equipment and } \\
\text { materials }\end{array}$ & 0.95 & 0.05 \\
\hline RC7. & $\begin{array}{l}\text { Economic and } \\
\text { Financial Aspects }\end{array}$ & & \\
\hline RF16 & Payments by owner & 0.40 & 0.60 \\
\hline RF17 & Materials prices & 0.60 & 0.40 \\
\hline
\end{tabular}

\section{Influence Diagram of Risk Factors and Discussion}

\section{A. Manpower Aspects}

Aspects of labor is a crucial factor the successful implementation of a road and bridge projects. Labor used usually come from diverse backgrounds and educational different. To implement the project needed an experienced workforce and expertise. In the area of Papua, local labor force does not have sufficient expertise to work on the project, therefore it takes labor from outside Papua who have experience and expertise. This has an impact on the timing of bring in labor and rising costs of labor.

\section{B. Material and Equipment Aspects}

Distribution of materials and equipment in the area of Papua using transport that is still very limited. This relates to the territory of Papua in general which can only use air transport. Thus the impact on-time delivery of quality materials and equipment needed for the construction of roads and bridges. Availability of materials and equipment at the project site be constrained if the source material and equipment to be away from the project site or outside the island like material asphalt, cement, excavators, bulldozers, motor graders, tandem rollers and others. Hence the error in the estimation of the delivery schedule and the allocation of materials will affect the project completion time.

\section{Characteristic of Location Aspects}

Infrastructure construction of roads and bridges in the area of West Papua is a government attempt to connect a remote area with other remote areas so that these areas can be developed. Access to the project site is generally difficult with long distance. Access to the project site is generally difficult with long distance. However this is not overly hamper because contractors who carry out projects such roads and bridges. generally is a contractor who live in the area of Papua that has been familiar with the geography or natural region of West Papua.

\section{Natural and Social Aspects}

The weather in the area of West Papua recently changed often extreme and can affect the time of project implementation.

\section{E. Managerial Aspects}

Lack of managerial ability contractor or subcontractor may cause events that can mengakibatkan kegagalan in the implementation, prone to accidents and discomfort in work.

\section{F. Economic and Financial Aspects}

The failure of either party to perform its obligations or failure to pay the bill on the other hand, can result in substantial delays in the implementation of the project so that project implementation costs could be higher. Locations projects in remote areas, resulting in transportation costs of material and equipment becomes expensive.

Interaction between risk factors that affect the timing of the project, can be mapped by using the influence diagram shown in Figure 1

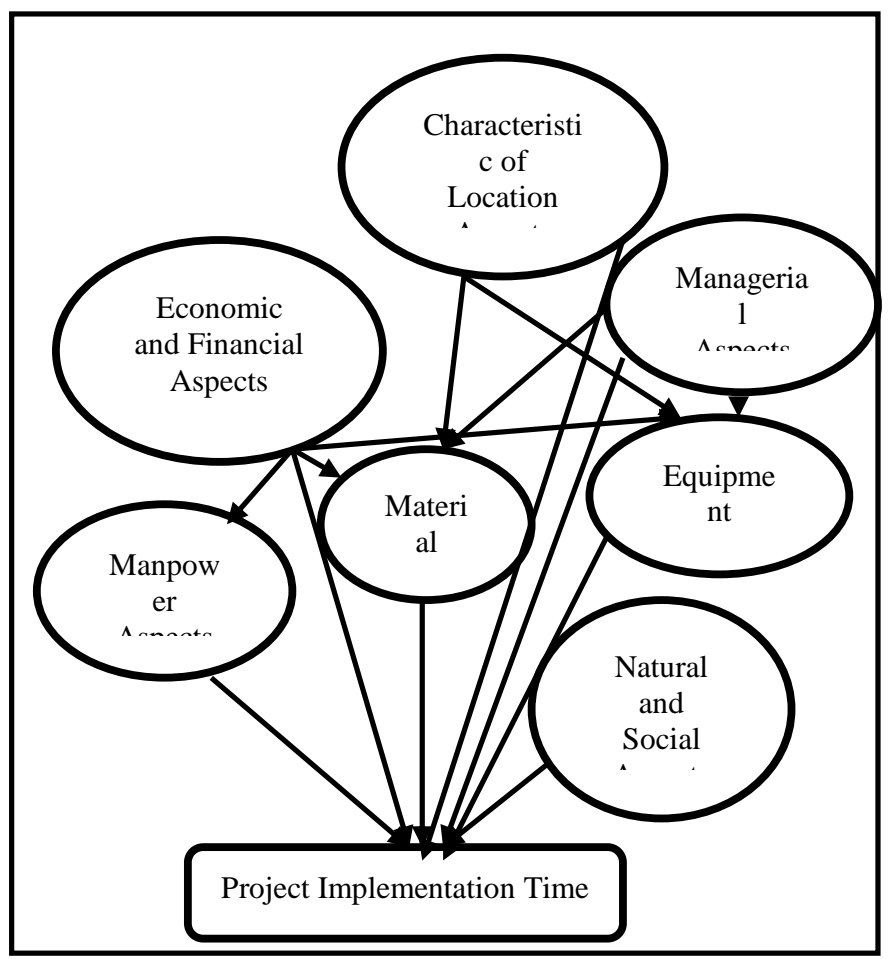

Figure 1. Influence Diagram of Risk Factor 
All of these risk factors can be anticipated earlier if all the interested parties to prepare everything well before the project is implemented.

\section{The probability of the risk categories occurring toward the Project Implementation time}

The probability of the risk categories occurring toward the Project Implementation time according to experts are shown in Table 4 below.

Table 4.

\begin{tabular}{|l|l|c|c|}
\hline No & \multicolumn{1}{|c|}{ RF and RC } & $\begin{array}{c}\text { Probability } \\
\text { of } \\
\text { Occurrence }\end{array}$ & $\begin{array}{c}\text { No } \\
\text { Occurrence } \\
\text { Probability }\end{array}$ \\
\hline RC1. & Manpower Aspects & 0.80 & 0.20 \\
\hline RC2. & Material Aspects & 0.95 & 0.05 \\
\hline RC3. & Equipment Aspects & 0.90 & 0.10 \\
\hline RC4. & $\begin{array}{l}\text { Characteristic of } \\
\text { Location Aspects }\end{array}$ & 0.50 & 0.50 \\
\hline RC5. & $\begin{array}{l}\text { Natural and Social } \\
\text { Aspects } \quad 0.80\end{array}$ & 0.20 \\
\hline RC6. & Managerial Aspects & 0.80 & 0.20 \\
\hline RC7. & $\begin{array}{l}\text { Economic and } \\
\text { Financial Aspects }\end{array}$ & 0.90 & 0.10 \\
\hline
\end{tabular}

Based on Figure 1 and Table 4, can be known the probability $(\mathrm{P})$ the risk category every aspect to the project implementation time .

The probability of the risk category of the project implementation time for roads and bridges $=$

$\mathrm{P}(\mathrm{RC} 1 \mid \mathrm{RC} 7)^{*} \mathrm{P}(\mathrm{RC} 7)+\mathrm{P}\left(\mathrm{RC} 1 \mid \mathrm{RC} 7^{\prime}\right)^{*} \mathrm{P}\left(\mathrm{RC} 7^{\prime}\right)+$

$\mathrm{P}(\mathrm{RC} 2 \mid \mathrm{RC} 4, \mathrm{RC} 6, \mathrm{RC} 7) * \mathrm{P}(\mathrm{RC} 4, \mathrm{RC} 6, \mathrm{RC} 7)$

P(RC2|RC4',RC6', RC7')*P(RC4',RC6', RC7')

$\mathrm{P}(\mathrm{RC} 3 \mid \mathrm{RC} 4, \mathrm{RC} 6, \mathrm{RC} 7) * \mathrm{P}(\mathrm{RC} 4, \mathrm{RC} 6, \mathrm{RC} 7)$

$\mathrm{P}(\mathrm{RC} 3 \mid \mathrm{RC} 4 \text { ',RC6', RC7' })^{*} \mathrm{P}\left(\mathrm{RC} 4{ }^{\prime}, \mathrm{RC}^{\prime}, \mathrm{RC} 7{ }^{\prime}\right)+\mathrm{P}(\mathrm{RC} 4)+$ $\mathrm{P}(\mathrm{RC} 5)+\mathrm{P}(\mathrm{RC} 6)+\mathrm{P}(\mathrm{RC} 7)$

\section{Conclusions}

Risk factors that may occur in the implementation of road and bridge projects in the area of West Papua, can have an impact on the project implementation time. These risk factors are classified into seven categories with the first dominant factor until the third in a sequence is $\mathrm{RII}=3.00, \mathrm{R}=1$ is Availability of Material(Material Aspects), Indigenous Land Issues( Natural and Social Aspects) and Schedule Delivery of Equipment and Material( Managerial Aspects); RII= 2,64, R=2 is Labor Expertise(Manpower Aspects), Quality of Material (Material Aspects), Land Acquisition (Natural and Social Aspects); and $\mathrm{RII}=2,52, \mathrm{R}=3$ is Availability of Equipment (Equipment Aspects). Mapping the risk factor for determining the relationship between factors so can be anticipated early.

\section{Acknowledgement}

This research was supported by the Ministry of Research, Technology and Higher Education of Indonesia. Therefore, the authors are grateful and thank you very much.

\section{References}

[1] Australian/New Zaeland Standard. (1999)," Risk Management”, AS/NSZ. 4360.

[2] Azwar, E. (2003), "Risk Analysis Framework Implementation Structure Contractors In Upper Bridge Type I-Girder and Box Girder", Thesis Civil Engineering,Construction Management, ITB-Bandung

[3] Chapman, C. dan Ward, S. (1999) : Project Risk Management, Processes Technique and Insights, John Willy \& Sons Ltd.

[4] Federation Internationale Des Ingenieurs Conseils. (1988) : Condition of Contract for works of Civil Engineering Construction, Part I General Conditions With From of Tender and Agreement.

[5] Flanagan, R. dan Norman, C. (1993) : Risk Management and Construction, Royal Intitution of Chartered Surveyors Grifis F.H. dan John V.F. Construction Planning for Engineering, Mc GrawHill International Edition.

[6] Latupeirissa, J.E.(2007), "The Framework of Contingency Cost Determination in The Construction Execution", Dissertation, Civil Engineering, Construction Management, ITB-Bandung

[7] Latupeirissa, J.E.(2014), "Uncertain Events That Resulting a Risk of an Increase in Construction Costs (Case Studies on Some of the Contractors in Indonesi", Second International Conference on Advances in Civil, Structural and Environmental Engineering-ACSEE 2014. ISBN 978-163248-030-9 doi : 10.15224/978-1-63248-030-9-161.Zurich. Switzerland

[8] Odeh, M. A., and Battaineh, H.T., (2002) : Causes of Construction Delay : Traditional Contract, Internasional Journal of Project Management, 20,pp 67-73.

[9] Silas Kendek, (2014), "The Factors Causing Delays in Road Improvement Project in the South Sorong districts of West Papua", Thesis. Civil Engineering. UKI Paulus. Makassar

[10] Smith, N J., Merna T., Jobling P. (2006) : Managing Risk : In Construction Project, Blackwell Publishing 2 Edition, ISBN - 13: 9781-4051-3012-7; ISBN - 10 : 1-4051-3012-1

About Author (s):

\begin{tabular}{|l|c|}
\hline $\begin{array}{l}\text { Dr.Josefine } \\
\text { Ernestine } \\
\text { Latupeirissa }\end{array}$ & $\begin{array}{c}\text { Infrastructure has an important role and } \\
\text { as one of the drivers of economic } \\
\text { growth and development. Construction } \\
\text { of roads and bridges in the area of West } \\
\text { Papua aims to support the distribution } \\
\text { of goods and human traffic and form a } \\
\text { spatial structure }\end{array}$ \\
\hline
\end{tabular}

